\title{
PERCEPTIONS OF STUDENTS REGARDING USE OF GOOGLE CLASSROOM AT UNIVERSITY LEVEL DURING COVID-19 \\ Bibi Ruqia ${ }^{*}$, Irfan Ullah Khan ${ }^{2}$, Hamid Khan ${ }^{3}$, Mati Ullah ${ }^{4}$, Zeenat Bibi ${ }^{5}$
}

${ }^{1 *, 5}$ M.Phil, Scholar, Department of Education \& Research, University of Lakki Marwat, KP, Pakistan; ${ }^{2}$ Assistant.Prof.

Department of Education \& Research, University of Lakki Marwat, KP, Pakistan; ${ }^{3}$ Lecturer, Institute of Business Administration, Gomal University D.I.Khan, KP, Pakistan; ${ }^{4}$ Lecturer, Department of Education \& Research, University of Lakki Marwat, KP, Pakistan.

Email: ${ }^{1 *}$ bibiruqiact@mail.com, ${ }^{2}$ thescholaredun@gmail.com, ${ }^{3}$ drhamidkhan@gu.edu.pk, ${ }^{4}$ educationistmrn@gmail.com, 5 zeenatmarwat823@gmail.com

Article History: Received on $27^{\text {th }}$ June 2021, Revised on $7^{\text {th }}$ July 2021, Published on $10^{\text {th }}$ July 2021

\section{Abstract}

Purpose of the study: The main focus of the researcher in the study was to investigate the opinions, views, beliefs, the respondents' attitudes towards Google Classroom during Covid-19.

Methodology: The study was descriptive. All on Campus enrolled students along with students of affiliated colleges with the University of Lakki Marwat where the population of the study in which all BS level on Campus students were taken as the target population of the study in which the total numbers of $(n=500)$ respondents comprised of samples as per L.R.Gay formula regarding determining the size of the sample. . A simple random sampling technique was used. Data was collected through a self-developed questionnaire of the 5-Points Likert scale. The validity and reliability of the research instrument were ensured. Data were statistically analyzed through SPSS by using Frequency, Percentage, and Regression.

Main Findings: The key findings of the study reveal that the majority of the respondents were in favor of Google Classroom during Covid-19 at BS level. Those who disagree with the online classes or Google Classroom showed negative concerns regarding it due to lack of facilities required for online classes or lack of resources essential for Google Classroom at the university level but overall, the views of the respondents were in favor of Google Classroom at University level in the University of Lakki Marwat, KP, Pakistan.

Applications of this study: The current study is highly significant for the government of the day in this modern world especially during Covid-19; the study could be quite effective and meaningful for Higher Education Institutions (HEIs), Policymakers, and HEC to ensure the quality of education at University level.

Novelty/Originality of this study: The existing study is new or unique in the field of education to promote the quality of education during calamities also as Covid-19 etc.

Keywords: Perceptions, BS Students, Google Classroom, Effects, Covid-19, University of Lakki Marwat, KP.

\section{INTRODUCTION}

According to (Sudarsana and Ketut, 2019), it is quite vital and mandatory for the government to facilitate all educational institutions with technological resources like Google Classroom LMS, internet, and Wi-Fi to use it for better e-teaching and e-learning purposes at higher or university levels. (Soni, 2018) found that Google Classroom ensures student's educational progress, better assessment, transparent and consistent academic work including assignments, presentations, and quizzes, etc. (Okmawati, 2020) pointed out that Google Classroom develops pedagogical and cognitive abilities of students. (Utomo, Sudaryanto and Saddhono, 2020) described that the teaching-learning process becomes highly effective due to Google Classroom in which students improve their communication, online face-to-face interaction, and questioning answering process via Google Classroom or online classes. (Henukh, Rosdianto and Oikawa, 2020) revealed that Google Classroom is the latest technological application to freely design and fully support teachers as well as students by ensuring online communication, organization, collaboration, assignments, quizzes, and presentation which are paperless. (Rahmad, Adria and Berutu, 2009) stated that Google Classroom improves the quality of education at higher or university levels in this modern era. (Al-Hunaiyyan, 2021) investigated that Google Classroom is the best solution to encourage students and teachers towards the continuation of online classes during Covid-19 by applying better Learning Management System upon students through the latest technology of the day.

According to (Putriand and Wahjuwibowo, 2020), the students of this modern world must ensure their expertise about technological tools like Zoom as video conferences for online purposes, Google Classroom for teaching-learning purposes, broadcast messages and WhatsApp group, etc. so that they may not be left behind in this modern world of technology. (Yasir, 2020) described that learning through Google Classroom or Online learning refers to internet or networking learning, it is also termed as e-learning or digital education including a full range of digital resources and tools to improve the quality of education or ensure technology-enhanced learning (TEL) so that students of the day could easily solve their educational issues through internet and they learn latest and updated knowledge within a short time. (Sintema, 2020) said that students are advised to wear face masks, wash hands, keep physical distance, avoid assemblies and gatherings by following all the rules and regulations suggested in lockdown due to Covid-19; and at the same time, 
they are emphasized to never miss Google Classroom or online classes whenever their institutions are closed. (Subedi et al., 2020) found that most of the educational institutions including schools, colleges, training centres or institutes, and higher educational institutions (universities) throughout the world have been suffered a lot due to Covid-19 and lockdown that are fatal big challenges for them to probe permanent solutions for Covid-19 pandemic; and in such circumstances, poor countries suffer a lot.

\section{PURPOSE OF THE STUDY}

The key target of the researcher in the study was to know students' views about using Google classroom during Covid19. The main purpose of the study for the researcher was also to probe the interest, command, and trend of students towards online classes especially Google Classroom activities during sensitive and pandemic time like Covid-19 in which the teaching-learning process is impossible without online classes or Google classroom to ensure academic courses. In this regard, the prime purpose of the study was to know the views and perceptions of the stakeholders and all those who were closely associated with educational activities about the use of Google Classroom during Covid-19.

\section{SIGNIFICANCE OF THE STUDY}

The study was highly significant for students to avail their e-learning opportunities during Covid-19 without wasting their precious time due to the closing of their institutions for months and months. The study was quite significant for teachers to utilize advanced technology like a laptop, online classes, Google classroom, Zoom facility, WhatsApp and skype, etc. for teaching purposes. The study was found quite significant for the education department, policymakers, educationists, scholars, and government to ensure quality education through online classes or Google classroom where the latest teaching-learning process was quite easy and essential by keeping in view the needs of the day in this modern world of education and technology. The study was also perceived as highly significant to utilize computerized and technological resources for the teaching-learning process during a pandemic time like Covid-19.

\section{OBJECTIVES OF THE STUDY}

The major objectives of the study were:

1. To examine the university readiness for online classes due to lockdown.

2. To probe students' perceptions about Google classroom during Covid-19.

3. To examine the interaction between students and teachers regarding Google classroom during Covid-19.

\section{LITERATURE REVIEW}

(Basilaia and Kvavadze, 2020) elaborated that the education system in Pakistan is badly collapsed due to pandemic Covid-19 and continuous lockdown for months and months; Google Classroom, Zoom, and other internet apps are key sources to maintain educational activities functional in a better way. (Dhawan, 2020) highlighted that Covid-19 is a very infectious and fatal disease due to which all educational institutions have been closed several times for a long time. (Abuhassna et al., 2020) described that both teachers and students have been facilitated in sharing their teaching-learning materials such as assignments, presentations, lectures, quizzes, and notes, etc. through Google Classroom and online resources while staying safe at their homes. (Adedoyin and Soykan, 2020) narrated that Google Classroom highly promoted teaching-learning activities and all educational institutions regarding its educational matters being closed for a long period due to which students suffer a lot. (Alanazi et al., 2020) stated that teachers and students happily embraced and prioritized experiences of digital skills like Google Classroom, Zoom, Skype and Whatsapp, etc. (Ali, Ramay and Shahzad, 2011) mentioned that students are dependent upon the internet, online classes, and Google Classroom to attain their academic and learning objectives where Covid-19 is spread everywhere. (Almusharraf and Khahro, 2020) highlighted that the government of the day implement the latest technology including the internet and Google Classroom for teaching-learning and administrative purposes in all educational institutions to ensure the quality of education.

(Almusharraf, Khahro and Arabia, 2020) found that education department conducts and arrange seminars, workshops, and training at all educational level so that both teachers and students get awareness regarding the concept of Google Classroom and other online resources utilized in promotion of quality education. (Aristovnik et al., 2020) explained that parents emphasize their children to utilize the latest technology for their learning purposes such as android mobile technology and laptop etc. (Baber, 2020) narrated that Google Classroom ensured innovative changes in the teachinglearning process at all levels. (Babinčáková and Bernard, 2020) described that the concept of traditional teachinglearning is reduced day by day due to Google Classroom and online learning by using the latest technology. (Bayrak, Moanes and Altun, 2020) asserted that teachers, students, scholars, educationists, and philosophers are highly inclined towards e-teaching and e-learning in this modern world of technology. (Beltekin and Kuyulu, 2020) stated that the education department, the government of the day, and policymakers are ensured their pursuit to produce manpower having awareness on the internet and online as well as Google Classroom.

(Bokayev, Torebekova and Davletbayeva, 2021) students of the day are ought to take interest in the internet and the latest technology so that they may able to learn and share their education-related problems with their teachers through Google Classroom, Whatsapp, and other online apps. (Chen et al., 2020) explained that students are mandatory to 
engage in pieces of training and workshops regarding Google Classroom and the use of the internet for learning purposes. (Choe et al., 2019) found that it's the responsibility of the government to implement the online teachinglearning process at Higher Education Institutions (HEIs) rather than following and adopting the traditional way of teaching and learning. (Coman et al., 2020). Social media, Facebook, WhatsApp, and Instagram should be used for educational purposes during calamities like pandemic Covid-19 when all educational institutions are closed. (Devon, Gregory, and Louise, 2020) revealed that Twitter and IMO should be fully utilized for online teaching-learning activities and students of the day are advised to learn all these technological programs that are useful and helpful in the promotion of education. (Naziya and Khan, 2020) explained that Google Classroom and online resources are very effective in promoting quality education.

\section{IMPORTANCE OF GOOGLE CLASSROOM}

The importance of Google classroom may not be neglected but rather we should appreciate it because of the following features of Google classroom.

1. The first point is that in Google classroom a teacher may use different colours or themes to make the classroom effective and interactive for learners. Similarly, a logo of the concerned university may also be a theme for Google classroom.

2. The second important point is that a teacher may reuse assignments, tests, or other content in future classes.

3. The third important point is that in Google classroom teachers may add facilitation for students which may not be possible in other web services like zoom. In Google Classroom teachers may add content like: assignments, such as video, PDFs, Google Docs, or Google Forms survey.

4. The fourth point is also very much important and may not be neglected but rather we should give proper weightage to it. Here the point is that in Google classroom teachers may share videos, links, or images from other websites with students. The practice will not only increase the subject matter knowledge of students but it will enable the learners to use various online sources to point to the solution of the problem and to make them independent learners.

5. The fifth point is that Google classroom is easy to use and accessible from all devices. All devices here mean that students may use them on personal computers, laptops, and even android set/ Mobile phones.

6. The sixth point is that Google classroom is unique in its functions in which the speeds up the assignment process are on top. It has made the assignment process for learners very easy and accessible for learners.

7. The seventh point is that of effective feedback in Google classroom.

8. The eighth point is that there is no need for paper in Google classroom. In Google Classroom, every task is assigned to learners online and feedback may also be submitted in soft from online to the concerned teacher.

9. The next point is that Google classroom is a clean and user-friendly interface.

10. Similarly, Google classroom is a great commenting system. We have seen in Google classroom that there is an open house for teachers as well as for learners to share their views in comments format. In Google classroom, teachers and students share comments, and then all the participants have access and opportunity if they want to share comments.

11. The next point is that Google classroom is for everyone.

\section{HYPOTHESIS OF THE STUDY}

$\mathbf{H}_{\mathbf{0}}$ : There was no interaction between students and teachers regarding Google Classroom during Covid-19 at the university level.

\section{RESEARCH METHODOLOGY}

\section{Study Design}

The design of the study was descriptive.

\section{The population of the Study}

All on Campus enrolled students along with students of affiliated colleges with the University of Lakki Marwat where the population of the study.

\section{Target Population of the Study}

All BS level On-Campus students were taken as the target population of the study.

\section{Sample of the Study}

The sample of $(n=500)$ respondents were randomly selected according to the L.R. Gay Sample size rule of thumb. 
Table 1: Sample selection by L.R. Gay Sample size rule of thumb

\begin{tabular}{ll}
\hline L.R. Gay, (2003) Sample Size & \\
\hline Population Size & Sample Size \\
\hline$<100$ & Entire Population \\
\hline$\sim 500$ & $50 \%(250)$ \\
\hline$\sim 1,500$ & $20 \%(300)$ \\
\hline$>5,000$ & 500 \\
\hline
\end{tabular}

\section{DATA COLLECTION TOOL (RESEARCH INSTRUMENT)}

Data were collected through a self-developed questionnaire of a 5-Points Likert scale.

\section{PILOT TESTING}

For pilot testing, the researcher ensured the validity and reliability of the research instrument. For validity purposes, the researcher distributed an initial draft of the questionnaire among field experts to bring refinement, rectification, and modification in the questionnaire where necessary while for reliability, the researcher administered a valid questionnaire among the sampled respondents to ensure reliability and internal consistency in the research instrument whose Chronbach's Alpha value was 0.809 falling in the better category as shown in the table below:

Table 2: Reliability of the Questionnaire Items

\begin{tabular}{ll}
\hline Cronbach's Alpha & Number of Items \\
\hline 0.809 & 40 \\
\hline
\end{tabular}

\section{MEASUREMENT SCALE}

Data were collected from the sampled respondents through a 5-points Likert scale with options:

Strongly Agree (SA): 5

Agree (A): 4

Undecided (UD): 3

Disagree (DA): 2

Agree (A): 1

Table 3: Responses of Respondents (BS Students) about Google Classroom

\begin{tabular}{lllllll}
\hline Level & Strongly Agree & Agree & Undecided & Disagree & Strongly Disagree & Total \\
\hline Frequency & 120 & 271 & 11 & 55 & 43 & 500 \\
\hline Percentage & 24.0 & 54.0 & 2.0 & 11.0 & 9.0 & 100 \\
\hline
\end{tabular}



Figure 3: Showing Responses of Respondents (BS Students) about Google Classroom

Table 3 shows the views of the respondents regarding Google classroom use in online classes at the university level in Khyber Pakhtunkhwa. Thus the responses of respondents indicate that the total number of the respondents was 500(100\%). 43(9\%) respondents strongly disagreed about Google classroom use in online classes at the university level in Khyber Pakhtunkhwa. 55 (11\%) respondents of the selected sample disagreed, 11(2\%) respondents show undecided, $271(54 \%)$ respondents of the present sample were agree and 120(24\%) respondents strongly agreed about Google 
classroom use in online classes at university level in Khyber Pakhtunkhwa. Thus in light of the above statements and views of students indicate the interest of learners and the effectiveness of Google classroom at the university level.

\section{DATA ANALYSIS}

Data were analyzed through SPSS by using Linear Regression to know the effects of Google Classroom or online classes on students at the university level.

\section{RESULTS OF THE STUDY}

Table 4: Effects of Google Classroom/Online Classes at University Level

\begin{tabular}{rrrrrrrrr}
\hline $\begin{array}{r}\text { Dependent } \\
\text { Variable }\end{array}$ & Predictor & $\mathbf{R}$ & $\begin{array}{r}\mathbf{R} \\
\text { Square }\end{array}$ & df & F-value & $\begin{array}{r}\text { P- } \\
\text { Value }\end{array}$ & $\begin{array}{r}\text { Beta } \\
\text { Score }\end{array}$ & Sig. \\
\hline BS Level Students & $\begin{array}{r}\text { Online Classes/ Google } \\
\text { Classroom }\end{array}$ & $.896^{\mathrm{a}}$ & .802 & 1 & 2017.127 & $.000^{\mathrm{a}}$ & .896 & .000 \\
& & & 498 & & & & \\
\hline
\end{tabular}

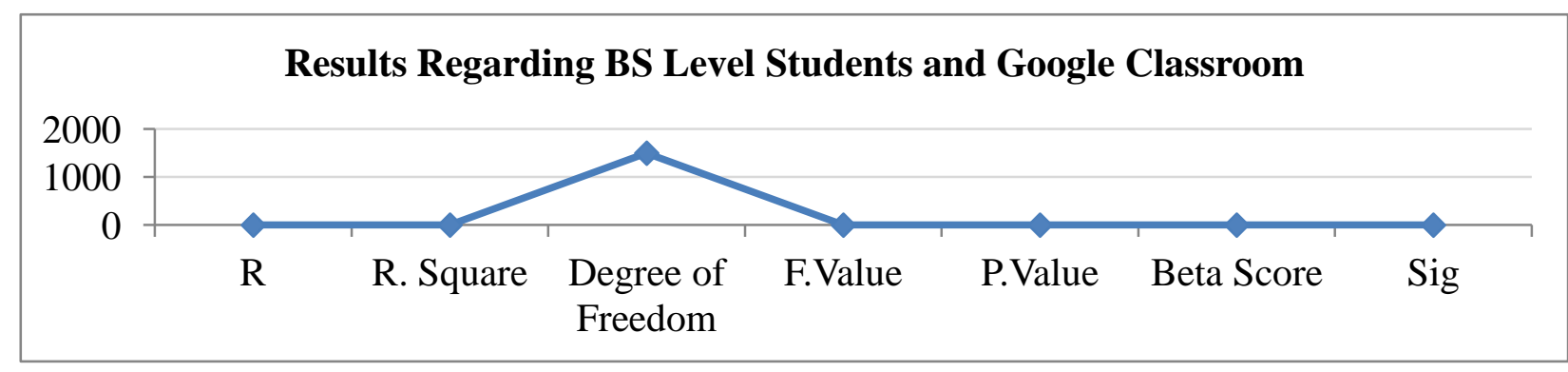

P> .05: (Shows Insignificance Influence)

P<.05: (Shows Significant Influence)

Figure 4: Result of the linear regression used to analyze the effect of Google classroom

Table 4 indicates the result of the linear regression used to analyze the effect of Google classroom on BS level students at the University of Lakki Marwat. The value of R square (.802) showing variance i.e. the square of multiple R (.896a), 2 indicates a correlation between the predictor (Use of Google Classroom) and BS level Students' learning (dependent variable). In the fifth (df) column1 shows independent variable(s) and the lower value indicates the total number of responses for the variables in equation i.e. $\{(500-1-1)\}=(498)$. F-value is 2017.127 which is significant at the (.000) level of significance. Similarly, the Beta score (.896) has also been found significant at the (.000a) level of significance, given in the eighth column of the mentioned table. The above inferences reveal the rejection of $\mathrm{H}_{0}$, which means that the sampled population perceives a significant relation or influence of Google classroom.

\section{DISCUSSION}

The current study revealed that perceptions of BS students were highly in favor of online classes or Google classroom. (Al-Hunaiyyan, 2021) highlighted the importance of online social media sources like Facebook, for learning purposes. The importance of it may not be neglected but rather appreciated. (Yasir, 2020) also stated the importance of communication in the digital world. (Putriand and Wahjuwibowo, 2020) have also described the social media and communication strategies.

\section{CONCLUSIONS}

The researcher concluded that the education sector tried its best to utilize ICT resources like online classes, Google classroom, Zoom, etc. for the teaching-learning process to ensure better and quality education at the university level for which the competent authority of the university did enough struggle to take help from HEC, HED, government, different mobile companies and other such organizations to facilitate both teachers and students and teachers regarding online teaching-learning opportunities by providing them with all possible internet facilities like Google classroom, zoom, and even WhatsApp facilities to teachers and students so that students' academic and learning careers may not suffer due to Covid-19 problem in which physical classes were not possible and all higher educational institutions and universities were closed due to Covid-19 That is why in light of the findings of the study the following conclusions were set up which are the following:

1. The findings of the said study indicated the importance of Google Classroom in the teaching-learning process during the closure.

2. The findings of the study also indicated that Google classroom is quite helpful in the assignment, quiz, questions, and answers, etc. 


\section{LIMITATIONS OF STUDY}

The study was limited merely to online classes (Google classroom) at BS level in the University of Laki Marwat during Covid-19.

The study may be extended to MS/M.Phil and Ph.D. level by adding some mediators and moderators for which further time and resources may be ensured.

A qualitative study may be conducted to record the opinions of students regarding Google classroom.

The study may be clarified with the help of a better data collection strategy (i.e. interview, focus group, and observation), etc.

The study may be conducted in various universities to compare the responses of the study regarding Google classroom/online classes.

\section{SUGGESTIONS FOR FUTURE RESEARCH}

The researchers are advised to probe solutions for all problems occurring during online and Google classroom, Zoom, and other such technological applications that are used to facilitate teachers and students at the university level in the future.

The future researchers are further suggested to share all problems and issues related to e-teaching and learning as well as Google classrooms among high officials, the government of the time, education department, policy and decision-makers to bring betterment and improvement in online and internet systems or activities are either used in the teaching-learning process or Google classroom, zoom, and so on.

\section{CONTRIBUTION OF AUTHORS}

\begin{tabular}{ll}
\hline Authors & Contribution \\
\hline Bibi Ruqia (M.Phil Scholar) & $\begin{array}{l}\text { Bibi Ruqia is the main contributor in the development of the unique concept as } \\
\text { well as the theme of the study. }\end{array}$ \\
\hline $\begin{array}{l}\text { Dr. Irfan Ullah Khan and Dr. Mati } \\
\text { Ullah }\end{array}$ & $\begin{array}{l}\text { They performed drafting and several times revised the manuscript to rectify it } \\
\text { as it can. }\end{array}$ \\
\hline Dr. Hamid Khan and Zeenat Bibi & $\begin{array}{l}\text { They contributed to the interpretation of statistical analysis as well as statistical } \\
\text { procedures. }\end{array}$ \\
\hline
\end{tabular}

\section{REFERENCES}

1. Sudarsana, I., \& Ketut. (2019). The use of Google classroom in the learning process. 1st International Conference on Advance and Scientific Innovation (ICASI), IOP Conf. Series: Journal of Physics: 1-6. Conf. Series, 1175(2019), 012165. https://doi.org/10.1088/1742-6596/1175/1/012165

2. Soni, S. (2018). Optimalisasi penggunaan google classroom, e-learning \& blended learning sebagai media pembelajaran bagi guru dan siswa di smk negeri 1 bangkinang. Journal Pengabdian. UntukMu NegeRI, 2(1), 17-20. https://doi.org/10.37859/jpumri.v2i1.361

3. Okmawati, M. (2020). The Use of Google Classroom during Pandemic, Journal of English Language Teaching, 9(2), 371-382. https://doi.org/10.24036/jelt.v9i2.109293

4. Utomo, M.N., \& Sudaryanto, Y.M., \& Saddhono, K. (2020). Tools and Strategy for Distance Learning to Respond COVID-19 Pandemic in Indonesia. Ingénierie des Systèmes d'Information Journal, 25(3), 383-390. https://doi.org/10.18280/isi.250314

5. Henukh, A., Rosdianto, H., \& Oikawa, S. (2020). Implementation of Google Classroom as Multimedia Learning. Jurnal Ilmu Pendidikan Fisika (JIPF), 5(1), 38-49. https://doi.org/10.26737/jipf.v5i1.1539

6. Rahmad, R.M., Adria, W., \& Berutu, N. W. (2018). Lumbantoruan, and M. Sintong. Google classroom implementation in Indonesian higher education. Journal of Physics: Conference Series, Volume 1175, 1st International Conference on Advance and Scientific Innovation, 1175(1), 23-24. https://doi.org/10.1088/17426596/1175/1/012153

7. Al-Hunaiyyan, A. (2021). Human-computer interaction perspective on mobile learning: gender and social implications. International Journal of Interactive Mobile Technologies, 1(2), 4-20. https://doi.org/10.3991/ijim .v15i11.21367

8. Putriand, C.M., \& Wahjuwibowo, S.I. (2020). Social Media and Communications Strategies Nyambu Village Tabanan Bali to Increase Tourist eco-tourism, Elementary Education Online, 20(4), 389-395.

9. Yasir, M.S. (2020). Communication in the Digital World: An Evaluation of Orthography of WhatsApp Messaging. Elementary Education Online, 20(4), 1809-1821.

10. Sintema, E. J. (2020, April 7). Effect of COVID-19 on the performance of grade 12 students: Implications for STEM education. EURASIA Journal of Mathematics, Science and Technology Education, 16(7), 1-6. https://doi.org/10.29333/ejmste/7893 
11. Subedi, S., Nayaju, S., Subedi, S., Shah, S. K., \& Shah, J. M. (2020). Impact of e-learning during COVID-19 pandemic among nursing students and teachers of Nepal. International Journal of Science and Healthcare Research, 5(3), 9.

12. Basilaia, G., \& Kvavadze, D. (2020). Transition to online education in schools during a SARS-CoV-2 coronavirus (COVID-19) pandemic in Georgia. Pedagogical Research, 5(4), 10. https://doi.org/10.2 9333/pr/7937

13. Dhawan, S. (2020). Online learning: A panacea in the time of COVID-19 crises. Journal of Educational Technology, 49(1), 5-22. https://doi.org/10.1177/0047239520934018

14. Abuhassna, H., Al-Rahmi, W. M., Yahya, N., Zakaria, M. A. Z. M., Kosnin, A. B. M., \& Darwish, M. (2020). Development of a new model on utilizing online learning platforms to improve students' academic achievements and satisfaction. International Journal of Educational Technology in Higher Education, 17(1), 123. https://doi.org/10.1186/s41239-020-00216-Z

15. Adedoyin, O. B., \& Soykan, E. (2020). Covid-19 pandemic and online learning: The challenges and opportunities. Interactive Learning Environments, 1-13. https://doi.org/10.1080/10494820.2020.1813180

16. Alanazi, A. A., Frey, B. B., Niileksela, C., Lee, S. W., Nong, A., \& Alharbi, F. (2020). The role of task value and technology satisfaction in student performance in graduate-level online courses. TechTrends, 64(6), 922930. https://doi.org/10.1007/s11528-020-00501-8

17. Ali, A., Ramay, M. I., \& Shahzad, M. (2011). Key factors for determining student satisfaction in distance learning courses: A study of Allama Iqbal Open University (AIOU) Islamabad, Pakistan. Turkish Online Journal of Distance Education, 12(2), 114-127. https://doi.org/10.30935/cedtech/6047

18. Almusharraf, N. M., \& Khahro, S. H. (2020). Students' satisfaction with online learning experiences during the COVID-19 pandemic. International Journal of Emerging Technologies in Learning, 15(21), 246-267. https://doi.org/10.3991/ijet.v15i21.15647

19. Almusharraf, N. M., Khahro, S. H., \& Arabia, S. (2020). Students' satisfaction with online learning experiences during the COVID-19 pandemic. International Journal of Emerging Technologies in Learning, 15(21), 246267. https://doi.org/10.3991/ijet.v15i21.15647

20. Aristovnik, A., Keržič, D., Ravšelj, D., Tomaževič, N., \& Umek, L. (2020). Impacts of the COVID-19 pandemic on the life of higher education students: A global perspective. Sustainability (Switzerland), 12(20), 134. https://doi.org/10.3390/su12208438

21. Baber, H. (2020). Determinants of students' perceived learning outcome and satisfaction in online learning during the pandemic of COVID19. Journal of Education and E-Learning Research, 7(3), 285-292. https://doi.org/10.20448/journal.509.2020.73.285.292

22. Babinčáková, M., \& Bernard, P. (2020). Online experimentation during covid-19 secondary school closures: Teaching methods and student perceptions. Journal of Chemical Education, 97(9), 3295-3300. https://doi.org/10.1021/acs.jchemed.0c00748

23. Bayrak, D. F., Moanes, D. M., \& Altun, D. A. (2020). Development of online course satisfaction scale. Turkish Online Journal of Distance Education, 21(4), 110-122. https://doi.org/10.17718/tojde.803378

24. Beltekin, E., \& Kuyulu, İ. (2020). The effect of Coronavirus (Covid19) outbreak on education systems: Evaluation of distance learning system in Turkey. Journal of Education and Learning, 9(4), 1. https://doi.org/10.5539/jel.v9n4p1

25. Bokayev, B., Torebekova, Z., \& Davletbayeva, Z. (2021). Distance learning in Kazakhstan: Estimating parents' satisfaction of educational quality during the coronavirus distance learning in Kazakhstan: Estimating parents' satisfaction abstract. Technology, Pedagogy, and Education, 30(3) 1-13. https://doi.org/10.1080/14759 $\underline{\text { 39X.2020.1865192 }}$

26. Chen, T., Peng, L., Jing, B., Wu, C., Yang, J., \& Cong, G. (2020). The impact of the COVID-19 pandemic on user experience with online education platforms in China. Sustainability (Switzerland), 12(18), 1-31. https://doi.org/10.3390/su12187329

27. Choe, R. C., Scuric, Z., Eshkol, E., Cruser, S., Arndt, A., Cox, R., \& Crosbie, R. H. (2019). Student satisfaction and learning outcomes in asynchronous online lecture videos. CBE Life Sciences Education, 18(4), 1-14. https://doi.org/10.1187/cbe.18-08-0171

28. Coman, C., Țîru, L. G., Meseșan-Schmitz, L., Stanciu, C., \& Bularca, M. C. (2020). Online teaching and learning in higher education during the coronavirus pandemic: Students' perspective. Sustainability (Switzerland), 12(24), 1-22. https://doi.org/10.3390/su122410367

29. Devon, E. M., Gregory, A. P., Louise, C. I. (2020). Global resource shortages during COVID-19: Bad news for low-income countries. PLOS One, 12-14(7), 1-3. https://doi.org/10.1371/journal.pntd.0008412

30. Naziya, H., \& Khan, N. H. (2020). Online teaching-learning during Covid-19 pandemic: Students'. The Online Journal of Distance Education and E-Learning, 8(4), 202-213. 